\title{
Epifaunal community response to iceberg-mediated environmental change in McMurdo Sound, Antarctica
}

\author{
Stacy Kim ${ }^{1, *}$, Kamille Hammerstrom ${ }^{1}$, Paul Dayton ${ }^{2}$ \\ ${ }^{1}$ Moss Landing Marine Labs, 8272 Moss Landing Rd., Moss Landing, CA 95039, USA \\ ${ }^{2}$ Scripps Institution of Oceanography, UC San Diego, 9500 Gilman Drive \#0227, La Jolla, CA 92093-0227, USA
}

\begin{abstract}
High-latitude marine communities are dependent on sea ice patterns. Sea ice cover limits light, and hence primary production and food supply. Plankton, carried by currents from open water to areas under the sea ice, provides a transitory food resource that is spatially and temporally variable. We recorded epifaunal abundances at 17 sites in McMurdo Sound, Antarctica, over $12 \mathrm{yr}$, and found differences in communities based on location and time. The differences in location support patterns observed in long-term infaunal studies, which are primarily driven by currents, food availability, and larval supply. The temporal differences, highlighting 2004 and 2009 as years of change, match the altered persistence of sea ice in the region, caused by the appearance and disappearance of mega-icebergs. The temporal changes were driven by changes in abundance of species that filter feed on large particulates. The shift in current patterns that occurred due to mega-icebergs decreased the normal food supply in the region. In addition to the decrease in food availability, we suggest that the reduced light resulting from thicker-than-normal sea ice resulted in a shift to smaller phytoplankton. A change in food quality as well as quantity may have influenced the temporal change in epifaunal communities.
\end{abstract}

KEY WORDS: Long-term - Decadal - Benthic . Megafauna

\section{INTRODUCTION}

Polar regions are responding to climate change faster than other regions of our planet (Baettig et al. 2007, IPCC 2014), and climate change has had signif-

${ }^{*}$ Corresponding author: skim@mlml.calstate.edu

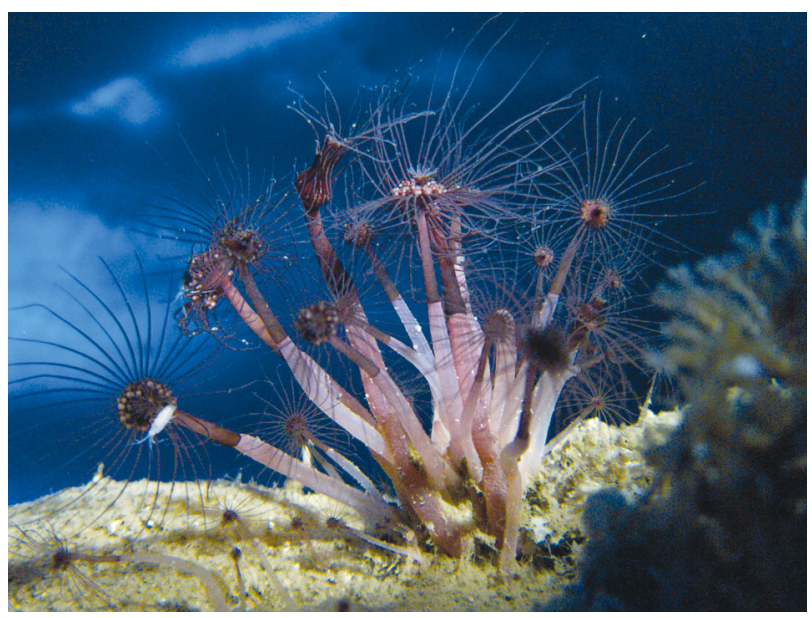

Benthic communities in Antarctica show temporal shifts in response to changes in sea ice and planktonic food supply. Zyzzyzus parvula is one key species.

Photo: Rob Robbins

icant ecological impacts (Doney et al. 2012). Climate change is not limited to increasing temperature, and ecologically, the most important environmental change in polar regions is in sea ice (Hoegh-Guldberg \& Bruno 2010). Rapid warming and ice loss have been occurring in the Arctic and the western Antarctic (Schofield et al. 2010, Maksym et al. 2012). In contrast, the Ross Sea, Antarctica, has been affected by a surface cooling trend due to increased winds and the resulting expansion of sea ice (through 2014). A shift in upper atmosphere circulation driven by the ozone hole has resulted in increased westerly winds, more sea ice formation in polynyas, and greater sea ice extent during winter/spring (Cavalieri \& Parkinson

() The authors 2019. Open Access under Creative Commons by Attribution Licence. Use, distribution and reproduction are unrestricted. Authors and original publication must be credited. 
2008, Holland \& Kwok 2012, Lee \& Feldstein 2013). In the Ross Sea area, the sea ice season has lengthened by $2 \mathrm{mo}$, and on the regional scale within McMurdo Sound, the sea ice is refreezing earlier, although it is also retreating further (Kim et al. 2018).

The influence of sea ice has for many years provided a working hypothesis on the underlying factors that control the ecosystem function of the high Antarctic benthos (Dayton \& Oliver 1977, Gutt 2001, Norkko et al. 2007, Lohrer et al. 2013), but the changing climate is modifying the distribution of ice, and consequently light. For the benthos, the amount of light for production is limited by the duration and thickness of ice and the amount of snow cover present over it (Eicken 1992, Gomez et al. 2009, Massom \& Stammerjohn 2010). In addition to the productivity dynamics, the shallow waters $(<30 \mathrm{~m})$ in some locations are regularly physically disturbed due to anchor ice formation, and larger disturbance events extending to greater depths due to icebergs (Lenihan \& Oliver 1995, Gutt 2001, Brown et al. 2004). In McMurdo Sound in particular, the sea ice is fast for most of the year, and reduces both light availability and nearshore scouring due to pack ice or growlers. Antarctic marine community structure is thus a function of ice and light dynamics (Barnes 1999, Smale 2007).

Although global changes in the habitat are occurring, much benthic work in McMurdo Sound has focused on direct human impacts (Lenihan et al. 1990, 1995, 2003, Lenihan 1992, Lenihan \& Oliver 1995, Conlan et al. 2004, 2010). Anthropogenic disturbances are small scale, localized, and well known (Dayton \& Robilliard 1971, Lenihan et al. 1990, Conlan et al. 2004). Local contamination is intense, but overall, the benthic habitat of McMurdo Sound is among the least human-disturbed in the world (Dayton et al. 1974, Dayton \& Oliver 1977 and references therein). With this low level of small-scale disturbance, McMurdo is well positioned as a prime location for long-term ecological research on decadal patterns and regime shifts. Regime shifts described in the literature are usually defined on the basis of key species (Francis et al. 1998, Chavez et al. 2003). Very few studies have shown how an entire community responds, although this may be done best in the benthos (Dayton \& Tegner 1984, Tegner et al. 1996, Tunberg \& Nelson 1998).

In McMurdo Sound, an overarching influence on benthic communities is the pattern of current flow that dictates whether the pelagic food supply from the Ross Sea is periodically ample, or meager and analogous to the deep sea (Dayton \& Oliver 1977).
The Ross Sea is the most productive region of the Southern Ocean, producing $>200 \mathrm{~g} \mathrm{C} \mathrm{m}^{-2}$ annually (Smith et al. 2006b). The McMurdo Sound benthos is nutritionally dependent on primary production from the Ross Sea (Barry \& Dayton 1988), with the annual phytoplankton bloom reaching McMurdo Station by local advection and seeding under the sea ice. Currents carry plankton southward along the east side of the Sound, under the permanent Ross Ice Shelf (Fig. 1). Flow then turns and moves northwards on the west side of the Sound, but the planktonic community is depauperate, and oligotrophic conditions predominate (Barry \& Dayton 1988). On the western side of the Sound the sea ice breaks out infrequently, and the thickness of the multiyear ice limits light and also in situ production (Stockton 1984, Dayton et al. 1986, Kim et al. 2018). The dramatic difference between planktonic and benthic production in the eutrophic eastern and oligotrophic western Sound has significant impacts on the structure of the benthic invertebrate communities (Dayton \& Oliver 1977, Dayton et al. 1986).

Starting in 2000-2001, the oceanographic conditions in McMurdo Sound were modified (Arrigo \& van Dijken 2003) following calving of the massive B-15 iceberg and grounding of a portion of it approximately $100 \mathrm{~km}$ northeast of McMurdo Station. This mega-iceberg blocked the Sound entrance and disrupted both inflowing currents carrying plankton from the open Ross Sea, and outflowing sea ice that normally allowed increased light levels and triggered a bloom of in situ producers during the summer (Arrigo et al. 2002, Hunt \& Hosie 2003, Seibel \& Dierssen 2003, Remy et al. 2008). The effect of these icebergs was a $40-70 \%$ reduction in phytoplankton production in 2000-2001 and 2002-2003 in the Ross Sea to the north of McMurdo Station, which resulted in changes in zooplankton composition (Arrigo et al. 2002, Arrigo \& van Dijken 2003, 2004, Seibel \& Dierssen 2003). The annual summer sea ice break-up did not reach McMurdo Station between 2000 and 2008 , resulting in a massive thickening of the sea ice (up to $9 \mathrm{~m}$ ) with associated light reduction, reduced light penetration, and reduced access to primary production (both local and advected).

During this time there was also a shift in the benthic infaunal community, with the abundances of common species decreasing, although no species were lost (Conlan et al. 2010, Thrush \& Cummings 2011). It is evident that infaunal individuals are able to survive for an extended period of time with low food input in the form of photosynthetic production, but it remains questionable whether they can reproduce 


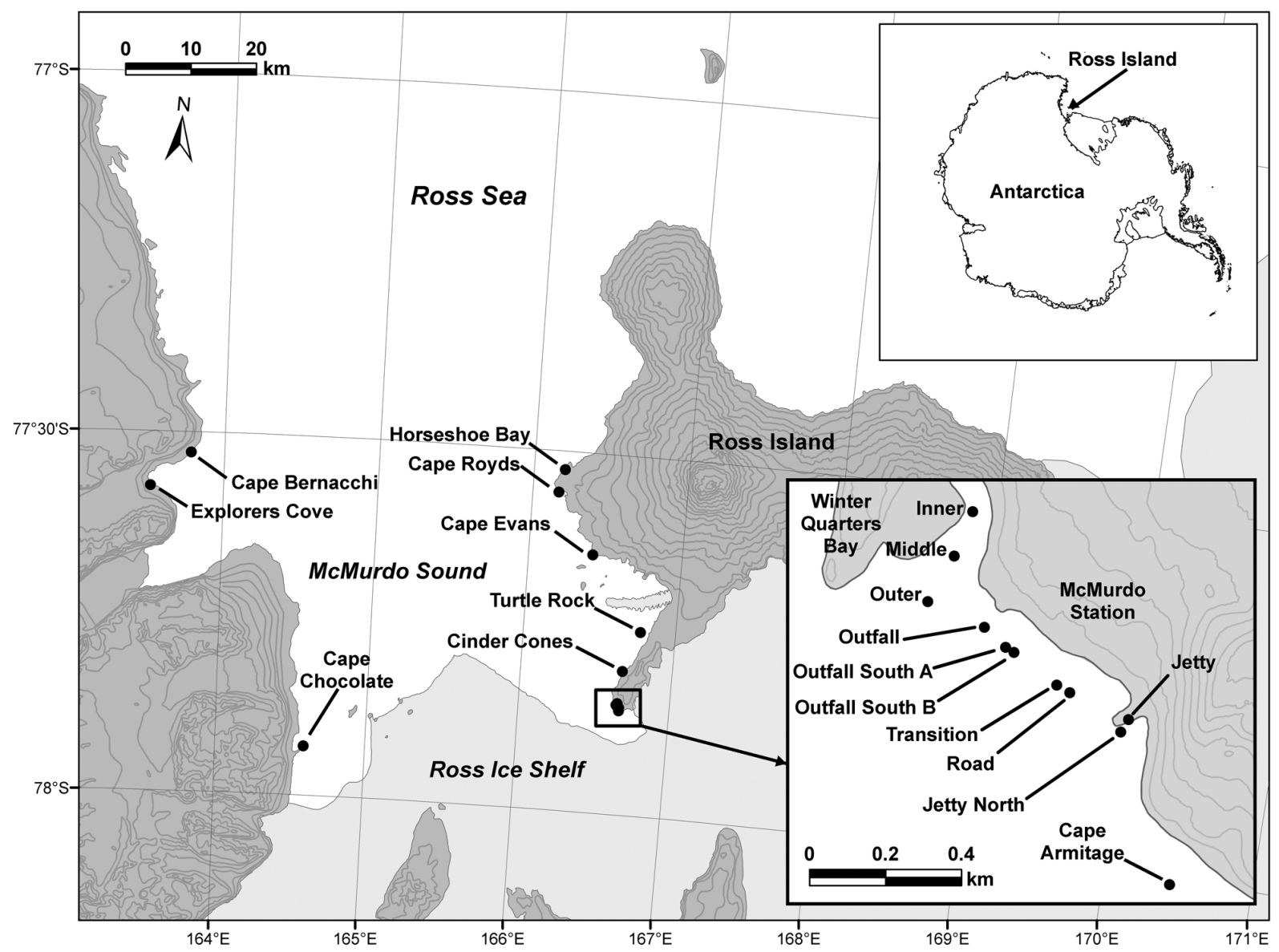

Fig. 1. McMurdo Sound, Antarctica, showing study sites

successfully. Antarctic benthic organisms are generalist feeders, with many species switching between suspension and deposit feeding (Dayton et al. 1974, 1994 and references therein, Slattery et al. 1997). Some taxa that are typically suspension feeders have developed adaptations that allow them to feed on the sediment surface; they are able to take advantage of the short, rich seasonal plankton bloom but are also able to persist on alternative, lower-value food sources (sensu the 'food bank,' Mincks et al. 2005, Smith et al. 2006a). Thus, the community may be slow to respond, with individuals persisting for their (long) Antarctic lifetimes but not replacing themselves in the population, and a slow decline may be the precursor to a catastrophic population crash.

In a broad perspective, ecologists are working to better understand large-scale and long-term natural processes, in part to interpret anthropogenically driven changes. However, it is difficult to differentiate alterations due to natural long-term changes, such as regime shifts, from those induced by cumulative anthropogenic changes that may drive ecosys- tems into much more stable phase shifts (Pauly et al. 1998, Scheffer et al. 2001). Regime shifts or any large ecosystem phase shift can be a result of the interactions of many ecological processes (e.g. competition, disturbance, dispersal; Dayton et al. 1999, Thrush et al. 2009). Alternatively, local-scale processes may involve simple feedback loops that build on each other to produce large-scale shifts (Dayton et al. 1999). In various habitats, data have been collected for decades, and the potential for understanding large-scale and long-term processes is exciting. One of the challenges that plague such efforts is incompatibility of data sets in space and/or time (Bramer 2013). Long-term data sets that have maintained standardized approaches or that have upgraded techniques and completed necessary comparative studies to preserve continuity are rare (Turner et al. 2014, Priscu 2016). Here we present a standardized long-term data set of the epifaunal benthic communities in McMurdo Sound, Antarctica, and evaluate ecological changes with respect to the local climatology. 


\section{MATERIALS AND METHODS}

\subsection{Sites, sampling and taxonomy}

Nineteen sites in McMurdo Sound, Antarctic (Table 1, Fig. 1), were sampled between 2002 and 2014, though not all sites were sampled in each year due to logistical constraints (Table 2). Each site encompassed at least 20 linear $\mathrm{m}$ at $18 \mathrm{~m}$ water depth, and was separated from adjacent sites by $30 \mathrm{~m}$ or more. Sample images were collected by SCUBA divers during the austral spring between September and November each year (Fig. S1 in the Supplement at www.intres.com/articles/suppl/m613p001_supp.pdf). Still and video cameras incorporated laser scaling systems so images were a consistent size and taken at a consistent height above the seafloor. Still cameras differed between years as technology changed; original cameras used film with a Nyquist limit of approximately 50 lines pairs $\mathrm{mm}^{-1}$, which is equivalent to a pixel size of approximately $9 \mu \mathrm{m}$, and the most recent digital camera images had a pixel size of $350 \mu \mathrm{m}$. While recording video transects, divers swam in straight lines for $>10 \mathrm{~m}$, reorienting between transects to not stray too far from the dive hole. To quantify common species, we used 10 replicate still images, and cropped each image to cover $1 \mathrm{~m}^{2}$. To quantify rare species, we used 3 replicate video transects encompassing $10 \mathrm{~m}^{2}$ each. For the buried species Laternula elliptica, we made in situ counts in 6 replicate $0.5 \times$ $0.5 \mathrm{~m}\left(0.25 \mathrm{~m}^{2}\right)$ areas. Species that could not be counted as individuals were not quantified (e.g. some hydroids, bryozoans, and sponges). Two $3.1 \mathrm{~cm}$ diameter, $5 \mathrm{~cm}$ deep cores were collected: one for grain size analysis, which was refrigerated until processing; and one for carbon and nitrogen analysis, which was frozen until analysis. Infaunal core samples were also collected, and results were published by Conlan et al. (2004, 2010); the most recent samples are still being processed and identified.

Organisms visible in each quadrat or transect were identified to the lowest possible taxonomic category and enumerated. Taxonomy follows that of the World Register of Marine Species (WoRMS, www.marinespecies.org/about.php). Individual taxa were counted in either quadrats or transects, depending on abun-

Table 1. Locations of sampling sites in McMurdo Sound, Antarctica (see also Fig. 1)

\begin{tabular}{|c|c|c|c|}
\hline Site & $\begin{array}{l}\text { Latitude } \\
\text { (South) }\end{array}$ & $\begin{array}{l}\text { Longitude } \\
\text { (East) }\end{array}$ & Habitat description \\
\hline Cape Armitage & $77^{\circ} 51.310^{\prime}$ & $166^{\circ} 40.070^{\prime}$ & $\begin{array}{l}\text { Spicule mat over medium sediments. Very abundant shell debris (Limatula). High light. } \\
\text { Strong currents. }\end{array}$ \\
\hline Jetty & $77^{\circ} 51.065^{\prime}$ & $166^{\circ} 40.057^{\prime}$ & Fine sediments. High light. \\
\hline Jetty North & $77^{\circ} 51.080^{\prime}$ & $166^{\circ} 39.985^{\prime}$ & Fine sediments. Low organics. Construction activities added gravel-to-cobble debris. \\
\hline Road & $77^{\circ} 51.008^{\prime}$ & $166^{\circ} 39.708^{\prime}$ & $\begin{array}{l}\text { Coarse sediments. Grain size decreased after 2003. Construction activities added a } \\
\text { small amount of gravel-to-cobble debris. Spicule mat in } 2004 \text {. }\end{array}$ \\
\hline Transition & $77^{\circ} 50.993^{\prime}$ & $166^{\circ} 39.633^{\prime}$ & $\begin{array}{l}\text { Medium sediments. Grain size decreased after 2003. Construction activities added a } \\
\text { large amount of gravel-to-cobble debris. Spicule mat in } 2014 \text {. }\end{array}$ \\
\hline Outfall South B & $77^{\circ} 50.933^{\prime}$ & $166^{\circ} 39.400^{\prime}$ & $\begin{array}{l}\text { Medium sediments. Grain size decreased after 2003. Construction activities added a } \\
\text { large amount of cobble-to-boulder debris. Shell debris (Laternula). }\end{array}$ \\
\hline Outfall South A & $77^{\circ} 50.923^{\prime}$ & $166^{\circ} 39.352^{\prime}$ & $\begin{array}{l}\text { Medium sediments. Grain size decreased after 2003. Construction activities added a } \\
\text { moderate amount of cobble-to-boulder debris. Shell debris (Laternula). }\end{array}$ \\
\hline Outfall & $77^{\circ} 50.888^{\prime}$ & $166^{\circ} 39.243^{\prime}$ & Fine sediments after 2002. High organics from decomposing sewage. \\
\hline WQB Outer & $77^{\circ} 50.833^{\prime}$ & $166^{\circ} 38.907^{\prime}$ & $\begin{array}{l}\text { Thin layer of coarse sediments over frozen sill. Fine organic sediments periodically } \\
\text { added from outfall. Strong currents, some ice scour (e.g. broken Laternula shells). }\end{array}$ \\
\hline WQB Middle & $77^{\circ} 50.778^{\prime}$ & $166^{\circ} 39.155^{\prime}$ & $\begin{array}{l}\text { Chemically contaminated fine sediments. Sand-to-gravel debris periodically added by } \\
\text { construction activities. Dead Laternula in situ. }\end{array}$ \\
\hline WQB Inner & $77^{\circ} 50.722^{\prime}$ & $166^{\circ} 39.348^{\prime}$ & $\begin{array}{l}\text { Chemically contaminated fine sediments. Construction activities added gravel-to-cobble } \\
\text { debris after } 2003 \text {. }\end{array}$ \\
\hline Cinder Cones & $77^{\circ} 48.007^{\prime}$ & $166^{\circ} 40.320^{\prime}$ & $\begin{array}{l}\text { Coarse sediments. Grain size decreased after 2002. Some ice scour (e.g. seafloor } \\
\text { scarring). Some shell debris (Laternula). }\end{array}$ \\
\hline Turtle Rock & $77^{\circ} 44.640^{\prime}$ & $166^{\circ} 46.183^{\prime}$ & $\begin{array}{l}\text { Coarse sediments on steep slope. Grain size decreased after 2002. Organic input from } \\
\text { local seal colony decreased over time. Shell debris common (Laternula). }\end{array}$ \\
\hline Cape Evans & $77^{\circ} 38.498^{\prime}$ & $166^{\circ} 25.118^{\prime}$ & $\begin{array}{l}\text { Coarse sediment with cobble-to-boulders. High light, encrusting corallines. Some ice } \\
\text { scour (e.g. icebergs present). }\end{array}$ \\
\hline Cape Royds & $77^{\circ} 33.464^{\prime}$ & $166^{\circ} 10.084^{\prime}$ & $\begin{array}{l}\text { Medium sediments with sand-to-cobble. Low organics. Heavy ice scour (e.g. broken } \\
\text { Laternula shells). }\end{array}$ \\
\hline Horseshoe Bay & $77^{\circ} 31.564^{\prime}$ & $166^{\circ} 11.986^{\prime}$ & Medium sediments with sand-to-gravel. Low organics. Some shell debris (Laternula). \\
\hline Cape Chocolate & $77^{\circ} 55.922^{\prime}$ & $164^{\circ} 35.555^{\prime}$ & Fine sediments with sand-to-gravel. Echinoderm ossicle debris. \\
\hline Explorers Cove & $77^{\circ} 34.573^{\prime}$ & $163^{\circ} 31.640^{\prime}$ & Fine sediments. Low organics. \\
\hline Cape Bernacchi & $77^{\circ} 31.743^{\prime}$ & $163^{\circ} 47.068^{\prime}$ & Fine sediments. Low organics. \\
\hline
\end{tabular}


Table 2. Number of epifaunal imagery samples collected in McMurdo Sound from 2002 through 2014. The first value is the number of replicate still images, and the second value is the number of replicate video transects. Blanks: no images taken that year

\begin{tabular}{|c|c|c|c|c|c|c|c|c|c|c|}
\hline Site & 2002 & 2003 & 2004 & 2007 & 2008 & 2009 & 2010 & 2011 & 2012 & 2014 \\
\hline Cape Armitage & $10 / 3$ & $10 / 3$ & $10 / 3$ & $10 / 3$ & $10 / 3$ & $10 / 3$ & $10 / 3$ & $10 / 3$ & $10 / 3$ & $10 / 3$ \\
\hline Jetty & & & $10 / 0$ & $10 / 3$ & $10 / 3$ & $10 / 3$ & $10 / 3$ & $10 / 3$ & $10 / 3$ & $10 / 3$ \\
\hline Jetty North & $10 / 3$ & $8 / 3$ & $10 / 0$ & & & & & & & \\
\hline Road & $10 / 3$ & $10 / 3$ & $10 / 3$ & $7 / 3$ & $10 / 3$ & $10 / 3$ & $10 / 3$ & $10 / 3$ & $10 / 3$ & $10 / 3$ \\
\hline Transition & $10 / 3$ & $10 / 3$ & $10 / 0$ & $6 / 3$ & $10 / 3$ & $10 / 3$ & $10 / 3$ & $10 / 3$ & $10 / 3$ & $10 / 3$ \\
\hline Outfall South B & $10 / 1$ & $10 / 3$ & $10 / 2$ & $10 / 3$ & $10 / 3$ & $10 / 3$ & $10 / 3$ & $10 / 3$ & $10 / 3$ & \\
\hline Outfall South A & $10 / 0$ & $10 / 3$ & $10 / 2$ & $10 / 3$ & $10 / 3$ & $10 / 3$ & $10 / 3$ & $10 / 3$ & $10 / 3$ & \\
\hline Outfall & $10 / 3$ & $10 / 2$ & $10 / 0$ & $10 / 3$ & $10 / 3$ & $10 / 0$ & $10 / 3$ & $10 / 3$ & $10 / 3$ & \\
\hline WQB Outer & $10 / 3$ & $0 / 1$ & $10 / 2$ & $10 / 3$ & $10 / 3$ & $9 / 0$ & $10 / 3$ & & $10 / 3$ & \\
\hline WQB Middle & $10 / 3$ & $0 / 1$ & $10 / 2$ & $10 / 3$ & $10 / 3$ & $10 / 0$ & $10 / 3$ & & $10 / 3$ & \\
\hline WQB Inner & $10 / 3$ & $0 / 2$ & $10 / 2$ & $10 / 3$ & $10 / 3$ & $10 / 0$ & $10 / 3$ & $10 / 3$ & $10 / 3$ & \\
\hline Cinder Cones & $10 / 3$ & $0 / 4$ & $11 / 0$ & $10 / 3$ & $10 / 3$ & $10 / 0$ & $10 / 3$ & $10 / 3$ & $10 / 3$ & $10 / 3$ \\
\hline Turtle Rock & $10 / 3$ & $10 / 3$ & $10 / 0$ & $10 / 3$ & $10 / 3$ & $10 / 0$ & $10 / 3$ & & $10 / 3$ & $10 / 3$ \\
\hline Cape Evans & $10 / 0$ & & & & & & & & & \\
\hline Cape Royds & & & & $10 / 0$ & & & & & & \\
\hline Horseshoe Bay & & & $10 / 0$ & & & & & & & \\
\hline Cape Chocolate & & & $10 / 0$ & & & & & & & \\
\hline Explorers Cove & $10 / 0$ & $0 / 3$ & $10 / 2$ & $10 / 3$ & $10 / 3$ & $8 / 0$ & $10 / 3$ & & & \\
\hline Cape Bernacchi & $10 / 3$ & $0 / 2$ & $10 / 3$ & & & & & & & \\
\hline
\end{tabular}

dance; we used a comprehensive and consistent species list, and for each site/year, we first analyzed quadrats, and subsequently transects, limiting the species list for transects to those that had not been found in quadrats. The counts were area-adjusted and combined into a single megafaunal data set, available at the Biological and Chemical Oceanography Data Management Office (BCO-DMO; https:// www.bco-dmo.org/dataset/745874/data).

\subsection{Environmental parameters}

Sediment grain size analyses were carried out with a Beckman-Coulter LS 13320 laser particle size analyzer attached to an aqueous module equipped with a pump and a built-in ultrasound unit. The measured size distributions were analyzed from $0.04 \mu \mathrm{m}$ to $2 \mathrm{~mm}$. Measurements of such a wide particle size range are possible because the particle sizer is composed of 2 units: a laser beam for conventional (Fraunhofer) diffraction (from $0.4 \mu \mathrm{m}$ to $2 \mathrm{~mm}$ ) and a polarized intensity differential scatter (PIDS) unit, which measures particles based on the Mie theory of light scattering (0.04 $\mu \mathrm{m}$; Beckman Coulter 2003). The sediment samples were dispersed in de-ionized water, and increasing amounts of the sediment solution were added to the aqueous module of the particle sizer until obscuration values of $8-12 \%$ and PIDS obscuration values of $48-52 \%$ were obtained. Data interpolation and statistical analyses were obtained with the laser particle sizer proprietary software (Beckman Coulter 2003).
Because all samples analyzed tend to log-normal grain size distributions in the $0.04 \mu \mathrm{m}$ to $2 \mathrm{~mm}$ spectrum, geometric rather than arithmetic statistics were applied to the values obtained by the logarithmically spaced size channels of the particle sizer.

For total organic carbon (TOC) and nitrogen analysis, frozen samples were thawed at room temperature and stirred, and approximately $5 \mathrm{~g}$ equivalent dry weight subsamples were treated with $5-10 \mathrm{ml}$ of 0.5-1.0 $\mathrm{M}$ reagent-grade $\mathrm{H}_{2} \mathrm{SO}_{4}$ as needed to remove all inorganic carbon. Samples were then dried at $60-70^{\circ} \mathrm{C}$, visually inspected to ensure complete removal of any carbonate shell fragments, and homogenized in a ball-mill. A modification of the hightemperature combustion method, using a Wheatstone bridge current differential, was used in a 440 Elemental Analyzer (Control Equipment). Combustion was at $<800^{\circ} \mathrm{C}$, below the $\mathrm{CaCO}_{3}$ decomposition temperature. The manufacturer's suggested procedures were followed on duplicate or triplicate 5$10 \mathrm{mg}$ aliquots, with sample variance $>10 \%$ leading to re-homogenizing and re-running the analysis. Calibration was with known standards using acetanilide or L-cystine every 20-30 machine sample runs, with $\pm 2 \%$ acceptable limits, and detection limits were $0.2 \mu \mathrm{g} \mathrm{mg}^{-1}$ carbon and $0.01 \mathrm{\mu g} \mathrm{mg}^{-1}$ nitrogen, dry weight. Quality control was maintained by analysis of National Research Council of Canada Marine Sediment Reference Material BCSS-1 at the beginning and end of each sample analysis set. All analyzed values were within the suggested criteria of $\pm 0.09 \%$ carbon, $\pm 0.008 \%$ nitrogen. Sediment data 
(physical and chemical) are available at the BCODMO (https://www.bco-dmo.org/dataset/746035/data).

Data on wind velocity and air temperature were obtained from the University of Wisconsin-Madison Antarctic Meteorological Research Center Program (ftp://amrc.ssec.wisc.edu/pub/mcmurdo/climatology/). Because sea ice formation and cover is influenced by conditions during the previous months, data from the summer-winter months (December-September) prior to sample collection were used, e.g. meteorological data from December 2010 through September 2011 were paired to biological data from September 2011 to November 2011.

\subsection{Statistical analysis}

We used multi-dimensional scaling (MDS) to provide a clear graphical display of the similarities (and differences) between all sites and times. Abundances were square root transformed to balance the effects of abundant and moderately abundant species. Bray Curtis similarities were then calculated, and similarity profile analysis (SIMPROF; PRIMER version 6) was used to distinguish groupings by dendrogram.
To determine which species characterized groups and were responsible for differences between groups, we used the SIMPER routine. Analysis was done at the genus/species level rather than aggregating to family, as is common for macrofaunal data sets, because in this study, depth was not a variable and sediment grain size was a measured parameter, so genus or species replacement within the same family was not a likely complication.

To examine changes over years, we used 1-way (year) permutational multivariate analyses of variance (PERMANOVAs) within each site, with PERMANOVA pairwise comparisons where appropriate.

To determine which of the measured environmental parameters (sediment characteristics, wind velocity, air temperature) matched observed biotic patterns, we ran the BIO-ENV routine on normalized environmental parameters, removed correlated factors (mode and median grain size, which were correlated with mean grain size), and used the BEST match procedure to determine which environmental Euclidian distance resemblance matrices generated from subsets of environmental variables showed the highest rank-based matrix correlation with the epifaunal sample Bray-Curtis similarity matrix.

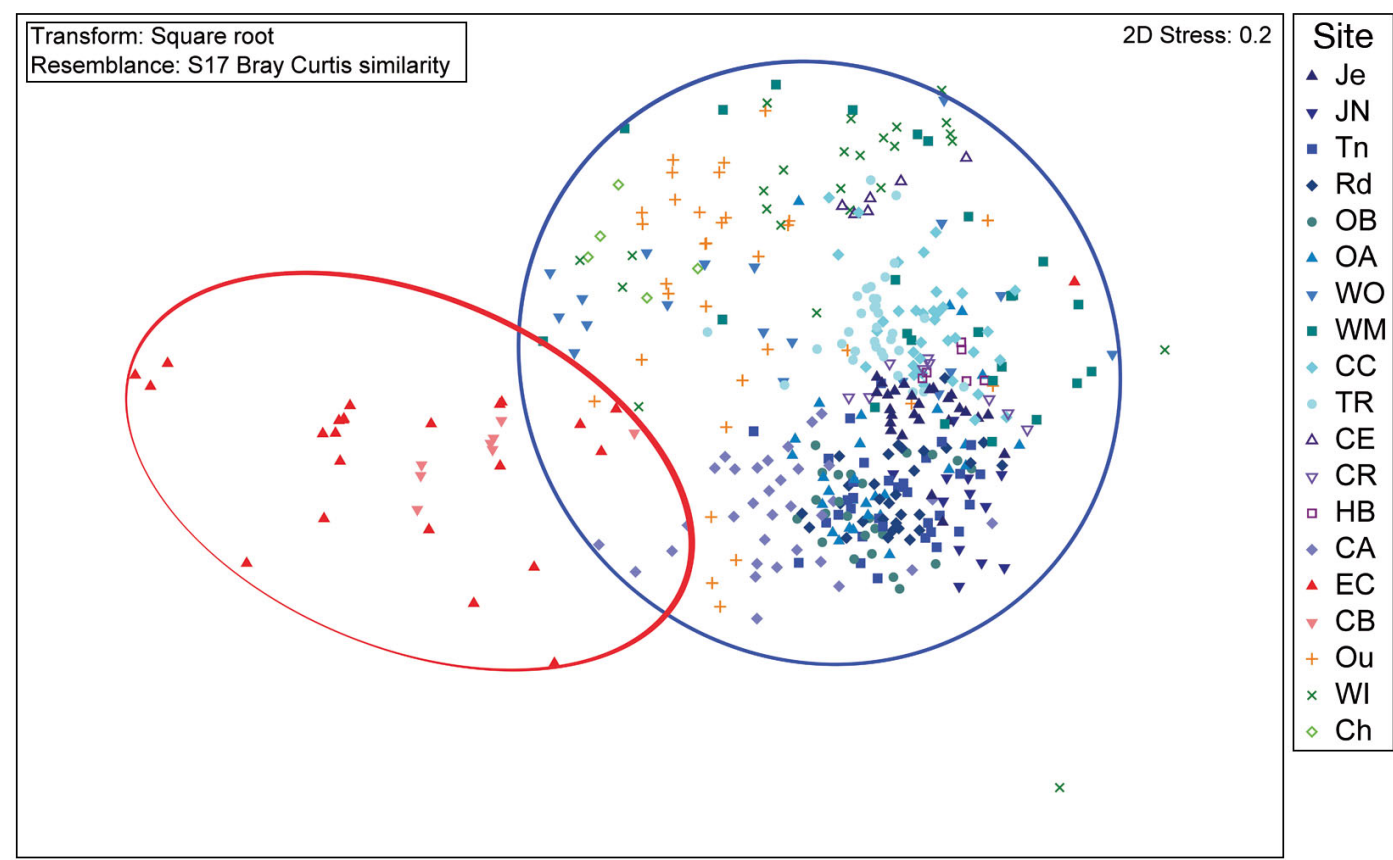

Fig. 2. Multi-dimensional scaling plot showing clustering of sites (see Fig. 1a for site locations). The main cluster (blue circle) includes sites on the east side of McMurdo Sound. Sites on the west side (red ellipse) group together. In this 2-dimensional representation, not all clusters are clearly distinct; the site Outfall (+) is separate ('Organic' group), and the site WQB Inner ( $\times$ ) is separate ('Chemical' group), as is the Temporal group (see Section 3.1 for full description). Note that the 3-dimensional stress was an acceptable value at 0.15 , although here the easier to visualize 2-dimensional representation is shown. Open symbols indicate sites that were only sampled once. Je: Jetty, JN: Jetty North, Tn: Transition, Rd: Road, OB: Outfall South B, OA: Outfall South A, WO: Winter Quarters Bay (WQB) Outer, WM: WQB Middle, CC: Cinder Cones, TR: Turtle Rock, CE: Cape Evans, CR: Cape Royds, HB: Horseshoe Bay, CA: Cape Armitage, EC: Explorers Cove, CB: Cape Bernacchi, Ou: Outfall, 
Table 3. Results of SIMPER analysis showing dominant taxa at each grouping of sites (East, West, Organic, Chemical, and Temporal), up to a cumulative $90 \%$ similarity. Avg.: average, Abun.: abundance, Sim.: similarity, SD: standard deviation, Contrib.: contributed, Cum.: cumulative. The average similarity within the East grouping was 44.50, West: 41.91, Organic: 28.95, Chemical: 59.77, and Temporal: 54.38

\begin{tabular}{|c|c|c|c|c|c|c|}
\hline Assemblage & Species & Avg. Abun. (\# m³) & Avg. Sim. & Sim./SD & Contrib. \% & Cum. \% \\
\hline \multirow[t]{3}{*}{ East } & Laternula elliptica & 5.69 & 27.86 & 1.77 & 62.60 & 62.60 \\
\hline & Odontaster validus & 2.83 & 9.32 & 0.76 & 20.93 & 83.53 \\
\hline & Parborlasia corrugatus & 0.92 & 3.01 & 0.69 & 6.77 & 90.30 \\
\hline \multirow[t]{2}{*}{ West } & Adamussium colbecki & 2.45 & 28.67 & 1.38 & 68.42 & 68.42 \\
\hline & Ophionotus victoriae & 0.97 & 10.95 & 0.85 & 26.12 & 94.54 \\
\hline \multirow[t]{4}{*}{ Organic } & Sterechinus neumayeri & 1.90 & 13.24 & 0.85 & 45.74 & 45.74 \\
\hline & Parborlasia corrugatus & 0.89 & 7.23 & 0.61 & 24.96 & 70.70 \\
\hline & Flabegraviera mundata & 0.65 & 3.03 & 0.41 & 10.48 & 81.17 \\
\hline & Trematomus bernacchii & 0.57 & 2.93 & 0.32 & 10.13 & 91.30 \\
\hline Chemical & Odontaster validus & 1.76 & 54.51 & 3.26 & 91.20 & 91.20 \\
\hline \multirow[t]{10}{*}{ Temporal } & Laternula elliptica & 6.44 & 19.25 & 3.29 & 35.39 & 35.39 \\
\hline & Zyzzyzus parvula & 3.75 & 8.25 & 1.21 & 15.16 & 50.56 \\
\hline & Alcyonium antarcticum & 2.91 & 8.14 & 2.10 & 14.96 & 65.52 \\
\hline & Edwardsia sp. & 1.97 & 2.58 & 0.60 & 4.75 & 70.27 \\
\hline & Pycnogonoidea & 1.39 & 2.49 & 0.78 & 4.58 & 74.85 \\
\hline & Isotealia antarctica & 0.95 & 1.90 & 0.88 & 3.49 & 78.34 \\
\hline & Sphaerotylus antarcticus & 1.08 & 1.86 & 0.74 & 3.43 & 81.77 \\
\hline & Parborlasia corrugatus & 1.03 & 1.85 & 0.77 & 3.39 & 85.16 \\
\hline & Sterechinus neumayeri & 0.86 & 1.48 & 0.67 & 2.73 & 87.89 \\
\hline & Odontaster validus & 0.82 & 1.44 & 0.74 & 2.65 & 90.53 \\
\hline
\end{tabular}

\section{RESULTS}

\subsection{Statistical groupings}

Five large groupings were distinguished by SIMPROF, as displayed by MDS (Fig. 2, see also Fig. S2). The groupings confirmed spatial differences established by previous studies (Dayton \& Oliver 1977, Conlan et al. 2004, 2010) of sites on the west side of the Sound, sites near a sewage outfall, sites near a chemical dumpsite, and sites on the east side of the Sound. The largest was comprised of East side sites Jetty, Jetty North, Transition, Road, Outfall South B, Outfall South A, Winter Quarters Bay (WQB) Outer, WQB Middle, Cinder Cones, and Turtle Rock. Two of the West side sites (Explorers Cove and Cape Bernacchi) formed another distinct group. The Outfall site was a distinct group, which we designated as 'Organic.' WQB Inner was another group of a single site, designated as 'Chemical.' The fifth group was temporally separated, including sites along the front of McMurdo Station (Road, Transition, Outfall South A, Outfall South B) after 2004, designated as 'Temporal.' Sites that were sampled only once generally formed their own small SIMPROF groups, though on a grosser scale in the cluster analysis, Cape Chocolate clustered with WQB Inner; and Cape Evans, Cape Royds, and Horseshoe Bay clustered with the other East side sites. Cape Armitage was highly vari- able between years in SIMPROF results, but generally grouped with East side sites in the cluster analysis.

\subsection{Taxonomic drivers}

Taxa contributing to the SIMPROF groupings (Table 3, see also Fig. S3) and the differences between them (Table 4) were determined by SIMPER analysis. Between the East side group and the Organic group (Outfall site), differences were due to the clam Laternula elliptica, the seastar Odontaster validus, and the urchin Sterechinus neumayeri, with the first 2 defining the East side assemblage, and S. neumayeri characteristic of the Organic group. The Chemical group (WQB Inner site) was characterized by relatively high proportion of $O$. validus, and differed from the East side group in L. elliptica and O. validus. Comparing the East and West side groups, differences were due to L. elliptica, $O$. validus, and the scallop Adamussium colbecki, with A. colbecki characterizing the West side assemblage. The later Temporal group differed from the East side group in the hydroid Zyzzyzus parvula, L. elliptica, the soft coral Alcyonium antarcticum, O. validus, and Edwardsia sp., with the first 3 characteristic of the Temporal group. Additional species (other than group-defining species) that contributed to differences were Parborlasia corrugatus between Organic and Chemical, 
Table 4. Results of SIMPER analysis showing contributions of taxa to differences between groupings of sites (East, West, Organic, Chemical, and Temporal), up to a cumulative $50 \%$ dissimilarity. Avg. diss.: average dissimilarity, AA: average abundance, 1 or 2 indicates the group, noted in the comparison column, $\mathrm{SD}=$ standard deviation, Contrib.: contributed, Cum.: cumulative

\begin{tabular}{|c|c|c|c|c|c|c|c|}
\hline Comparison & Avg. diss. & Species & AA 1 & AA 2 & Diss./SD & Contrib. \% & Cum. \% \\
\hline East (1) vs. West (2) & 95.77 & $\begin{array}{l}\text { Laternula elliptica } \\
\text { Odontaster validus } \\
\text { Adamussium colbecki }\end{array}$ & $\begin{array}{l}5.69 \\
2.83 \\
0.03\end{array}$ & $\begin{array}{l}0.18 \\
0.09 \\
2.45\end{array}$ & $\begin{array}{l}1.94 \\
1.04 \\
1.33\end{array}$ & $\begin{array}{l}32.15 \\
16.06 \\
15.11\end{array}$ & $\begin{array}{l}32.15 \\
48.21 \\
63.31\end{array}$ \\
\hline East (1) vs. Organic (2) & 83.24 & $\begin{array}{l}\text { Laternula elliptica } \\
\text { Odontaster validus } \\
\text { Sterechinus neumayeri }\end{array}$ & $\begin{array}{l}5.69 \\
2.83 \\
1.00\end{array}$ & $\begin{array}{l}0.33 \\
0.35 \\
1.90\end{array}$ & $\begin{array}{l}1.77 \\
1.02 \\
1.06\end{array}$ & $\begin{array}{l}34.25 \\
17.13 \\
11.70\end{array}$ & $\begin{array}{l}34.25 \\
51.38 \\
63.08\end{array}$ \\
\hline East (1) vs. Chemical (2) & 80.84 & $\begin{array}{l}\text { Laternula elliptica } \\
\text { Odontaster validus }\end{array}$ & $\begin{array}{l}5.69 \\
2.83\end{array}$ & $\begin{array}{l}0.00 \\
1.76\end{array}$ & $\begin{array}{l}2.10 \\
1.28\end{array}$ & $\begin{array}{l}44.04 \\
19.46\end{array}$ & $\begin{array}{l}44.04 \\
63.51\end{array}$ \\
\hline East (1) vs. Temporal (2) & 67.43 & $\begin{array}{l}\text { Zyzzyzus parvula } \\
\text { Laternula elliptica } \\
\text { Alcyonium antarcticum } \\
\text { Odontaster validus } \\
\text { Edwardsia sp. }\end{array}$ & $\begin{array}{l}0.19 \\
5.69 \\
0.16 \\
2.83 \\
0.60\end{array}$ & $\begin{array}{l}3.75 \\
6.44 \\
2.91 \\
0.82 \\
1.97\end{array}$ & $\begin{array}{l}1.49 \\
1.37 \\
2.18 \\
1.04 \\
0.93\end{array}$ & $\begin{array}{l}13.51 \\
12.63 \\
10.27 \\
9.09 \\
7.72\end{array}$ & $\begin{array}{l}13.51 \\
26.15 \\
36.42 \\
45.51 \\
53.23\end{array}$ \\
\hline Organic (1) vs. Chemical (2) & 85.43 & $\begin{array}{l}\text { Odontaster validus } \\
\text { Sterechinus neumayeri } \\
\text { Parborlasia corrugatus }\end{array}$ & $\begin{array}{l}0.35 \\
1.90 \\
0.89\end{array}$ & $\begin{array}{l}1.76 \\
0.11 \\
0.37\end{array}$ & $\begin{array}{l}1.59 \\
1.17 \\
0.98\end{array}$ & $\begin{array}{l}25.24 \\
22.94 \\
12.89\end{array}$ & $\begin{array}{l}25.24 \\
48.18 \\
61.08\end{array}$ \\
\hline Organic (1) vs. West (2) & 94.68 & $\begin{array}{l}\text { Adamussium colbecki } \\
\text { Sterechinus neumayeri } \\
\text { Ophionotus victoriae }\end{array}$ & $\begin{array}{l}0.19 \\
1.90 \\
0.07\end{array}$ & $\begin{array}{l}2.45 \\
0.00 \\
0.97\end{array}$ & $\begin{array}{l}1.42 \\
1.11 \\
1.03\end{array}$ & $\begin{array}{l}23.56 \\
17.77 \\
10.58\end{array}$ & $\begin{array}{l}23.56 \\
41.33 \\
51.91\end{array}$ \\
\hline Organic (1) vs. Temporal (2) & 86.91 & $\begin{array}{l}\text { Laternula elliptica } \\
\text { Zyzzyzus parvula } \\
\text { Alcyonium antarcticum } \\
\text { Edwardsia sp. }\end{array}$ & $\begin{array}{l}0.33 \\
0.07 \\
0.04 \\
0.16\end{array}$ & $\begin{array}{l}6.44 \\
3.75 \\
2.91 \\
1.97\end{array}$ & $\begin{array}{l}2.59 \\
1.54 \\
2.38 \\
0.91\end{array}$ & $\begin{array}{c}21.52 \\
12.68 \\
9.94 \\
6.43\end{array}$ & $\begin{array}{l}21.52 \\
34.21 \\
44.15 \\
50.58\end{array}$ \\
\hline Chemical (1) vs. West (2) & 95.39 & $\begin{array}{l}\text { Adamussium colbecki } \\
\text { Odontaster validus }\end{array}$ & $\begin{array}{l}0.05 \\
1.76\end{array}$ & $\begin{array}{l}2.45 \\
0.09\end{array}$ & $\begin{array}{l}1.73 \\
2.13\end{array}$ & $\begin{array}{l}32.55 \\
26.12\end{array}$ & $\begin{array}{l}32.55 \\
58.67\end{array}$ \\
\hline Chemical (1) vs. Temporal (2) & 2) 92.27 & $\begin{array}{l}\text { Laternula elliptica } \\
\text { Zyzzyzus parvula } \\
\text { Alcyonium antarcticum } \\
\text { Edwardsia sp. }\end{array}$ & $\begin{array}{l}0.00 \\
0.00 \\
0.00 \\
0.05\end{array}$ & $\begin{array}{l}6.44 \\
3.75 \\
2.91 \\
1.97\end{array}$ & $\begin{array}{l}3.08 \\
1.57 \\
2.48 \\
0.90\end{array}$ & $\begin{array}{c}23.47 \\
13.35 \\
10.49 \\
6.64\end{array}$ & $\begin{array}{l}23.47 \\
36.82 \\
47.31 \\
53.94\end{array}$ \\
\hline West (1) vs. Temporal (2) & 97.23 & $\begin{array}{l}\text { Laternula elliptica } \\
\text { Zyzzyzus parvula } \\
\text { Alcyonium antarcticum } \\
\text { Adamussium colbecki } \\
\text { Edwardsia sp. }\end{array}$ & $\begin{array}{l}0.18 \\
0.03 \\
0.02 \\
2.45 \\
0.00\end{array}$ & $\begin{array}{l}6.44 \\
3.75 \\
2.91 \\
0.02 \\
1.97\end{array}$ & $\begin{array}{l}2.88 \\
1.56 \\
2.47 \\
1.43 \\
0.89\end{array}$ & $\begin{array}{c}20.40 \\
11.86 \\
9.31 \\
7.69 \\
5.97\end{array}$ & $\begin{array}{l}20.40 \\
32.26 \\
41.58 \\
49.26 \\
55.23\end{array}$ \\
\hline
\end{tabular}

Ophionotus victoria between West and Organic, and Edwardsia sp. between Temporal and Organic, and Temporal and Chemical.

\subsection{Temporal patterns}

A subtler temporal pattern of change that was not obvious in the SIMPROF and cluster analysis showed in the results of PERMANOVAs, with 2004 and 2009 standing out as years of change. At all sites, communities were significantly different between years (Table 5). Post hoc pairwise comparisons were done to determine which years were different; following Anderson et al. (2008) we leave the p-values uncorrected but recognize only those differences that are significant for the majority of years. At 6 sites (Jetty,
Table 5. One-way PERMANOVA results for community differences between years, within each site

\begin{tabular}{|lcc|}
\hline Site & Pseudo- $F$ & $\mathrm{p}$ \\
\hline Cape Armitage & 6.2317 & 0.001 \\
Jetty North & 11.1500 & 0.001 \\
Jetty & 8.4097 & 0.001 \\
Road & 5.0034 & 0.001 \\
Transition & 4.9325 & 0.001 \\
Oufall South B & 4.3032 & 0.001 \\
Outfall South A & 4.0254 & 0.001 \\
Outfall & 4.5410 & 0.001 \\
WQB Outer & 4.2014 & 0.001 \\
WQB Middle & 2.6553 & 0.004 \\
WQB Inner & 2.6185 & 0.001 \\
Cinder Cones & 9.6984 & 0.001 \\
Turtle Rock & 4.8926 & 0.001 \\
Explorers Cove & 2.8135 & 0.001 \\
Cape Bernacchi & 3.2670 & 0.022 \\
\hline
\end{tabular}


Table 6. Significant PERMANOVA pairwise test results. Bold indicates significant differences in the majority of comparisons at the $\mathrm{p}<0.05$ level. Dashes indicate comparisons that could not be made because years were not sampled; blanks are where years cannot be compared to themselves

\begin{tabular}{|lcccccccccc|}
\hline Site - Year & 2002 & 2003 & 2004 & 2007 & 2008 & 2009 & 2010 & 2011 & 2012 & 2014 \\
\hline Cape Armitage - 2009 & $\mathbf{0 . 0 1 1}$ & $\mathbf{0 . 0 1 5}$ & 0.098 & $\mathbf{0 . 0 2 8}$ & 0.242 & & $\mathbf{0 . 0 3 6}$ & $\mathbf{0 . 0 1 7}$ & $\mathbf{0 . 0 1 3}$ & $\mathbf{0 . 0 1 2}$ \\
Jetty North - 2004 & $\mathbf{0 . 0 1 9}$ & $\mathbf{0 . 0 1 3}$ & & - & - & - & - & - & - & - \\
Jetty - 2004 & - & - & & $\mathbf{0 . 0 1 3}$ & $\mathbf{0 . 0 1 1}$ & $\mathbf{0 . 0 1 3}$ & $\mathbf{0 . 0 1 7}$ & $\mathbf{0 . 0 1 2}$ & $\mathbf{0 . 0 1 5}$ & $\mathbf{0 . 0 0 8}$ \\
Transition - 2004 & - & - & & $\mathbf{0 . 0 1 5}$ & $\mathbf{0 . 0 1 3}$ & $\mathbf{0 . 0 1 6}$ & $\mathbf{0 . 0 0 9}$ & $\mathbf{0 . 0 1 1}$ & $\mathbf{0 . 0 0 9}$ & $\mathbf{0 . 0 1 8}$ \\
Outfall South A - 2002 & & $\mathbf{0 . 0 1 6}$ & $\mathbf{0 . 0 4 0}$ & $\mathbf{0 . 0 1 2}$ & $\mathbf{0 . 0 1 2}$ & $\mathbf{0 . 0 1 6}$ & $\mathbf{0 . 0 1 2}$ & $\mathbf{0 . 0 1 3}$ & $\mathbf{0 . 0 1 2}$ & - \\
Outfall - 2004 & $\mathbf{0 . 0 1 2}$ & $\mathbf{0 . 0 2 2}$ & & $\mathbf{0 . 0 3 9}$ & $\mathbf{0 . 0 1 3}$ & 0.267 & $\mathbf{0 . 0 1 8}$ & $\mathbf{0 . 0 1 7}$ & $\mathbf{0 . 0 2 7}$ & - \\
Outfall - 2009 & $\mathbf{0 . 0 1 2}$ & $\mathbf{0 . 0 1 8}$ & 0.267 & 0.179 & 0.098 & & $\mathbf{0 . 0 2 3}$ & $\mathbf{0 . 0 1 6}$ & $\mathbf{0 . 0 3 6}$ & - \\
WQB Outer - 2009 & $\mathbf{0 . 0 2 9}$ & - & 0.253 & $\mathbf{0 . 0 2 9}$ & $\mathbf{0 . 0 3 5}$ & & $\mathbf{0 . 0 1 3}$ & - & $\mathbf{0 . 0 2 7}$ & - \\
WQB Middle - 2004 & 0.100 & 0.325 & & 0.106 & 0.112 & $\mathbf{0 . 0 4 1}$ & 0.116 & - & 0.099 & - \\
WQB Inner - 2009 & 0.083 & 0.133 & 0.074 & $\mathbf{0 . 0 3 0}$ & 0.068 & & $\mathbf{0 . 0 2 0}$ & $\mathbf{0 . 0 1 1}$ & $\mathbf{0 . 0 1 6}$ & - \\
Cinder Cones - 2004 & 0.921 & $\mathbf{0 . 0 2 7}$ & & $\mathbf{0 . 0 2 3}$ & $\mathbf{0 . 0 4 4}$ & $\mathbf{0 . 0 1 2}$ & $\mathbf{0 . 0 0 9}$ & $\mathbf{0 . 0 1 3}$ & $\mathbf{0 . 0 0 9}$ & $\mathbf{0 . 0 1 5}$ \\
Turtle Rock - 2004 & 0.494 & $\mathbf{0 . 0 1 1}$ & & 0.195 & $\mathbf{0 . 0 1 4}$ & 0.163 & $\mathbf{0 . 0 2 1}$ & - & 0.191 & $\mathbf{0 . 0 1 3}$ \\
Turtle Rock - 2009 & 0.834 & $\mathbf{0 . 0 1 2}$ & 0.163 & 0.601 & $\mathbf{0 . 0 1 9}$ & & 0.171 & - & 0.726 & $\mathbf{0 . 0 1 2}$ \\
Explorers Cove - 2002 & & $\mathbf{0 . 0 1 0}$ & 0.082 & $\mathbf{0 . 0 3 2}$ & $\mathbf{0 . 0 2 5}$ & 0.550 & $\mathbf{0 . 0 2 5}$ & - & - & - \\
Explorers Cove -2009 & 0.550 & $\mathbf{0 . 0 1 2}$ & 0.177 & 0.309 & $\mathbf{0 . 0 3 8}$ & & 0.083 & - & - & - \\
\hline
\end{tabular}

Jetty North, Transition, Outfall, Cinder Cones, and Turtle Rock), communities in 2004 were different from other years (Table 6, see also Table S1). At 4 sites (Cape Armitage, Outfall, WQB Outer, and WQB Inner), communities in 2009 were different from other years. Four sites (Road, Outfall South B, WQB Middle, and Cape Bernacchi) had no significant pairwise comparisons despite overall test significance. Communities in 2002 were significantly different at 2 sites (Outfall South A and Explorers Cove).

\subsection{Environmental parameters}

Measured environmental conditions did not generally correlate with community structure. Results of BEST analysis indicated that none of the measured factors, i.e. sediment grain size, sediment TOC, sediment $\mathrm{N}$, wind, or air temperature, was strongly correlated with the spatial or temporal distribution of benthic communities. The best variable combination had fairly low correlation $(\rho=28 \%$ ), and was primarily driven by the percentage of sediment in the 64-500 $\mu \mathrm{m}$ range, along with TOC, skewness, kurtosis, and to a lesser extent percent sediment in the $<63 \mu \mathrm{m}$ range.

\section{DISCUSSION}

\subsection{Temporal patterns}

The main temporal change observed was a difference in 2004, which occurred at some, but not all, of the East side sites (Jetty, Jetty North, Transition, Outfall, Cinder Cones, and Turtle Rock). A similar shift in infaunal communities was observed by Conlan et al. (2010) that began in 2003, and correlated with the initiation of wastewater treatment at McMurdo Station in January 2003. However, Conlan et al. (2010) distinguished between sewage-impacted and non-impacted infaunal communities and noted that changes occurred in both, suggesting that the larger-scale phenomenon of mega-icebergs blocking McMurdo Sound, which began in 2000, also influenced the change. The mega-icebergs changed the current pattern and provision of planktonic food to McMurdo Sound (Arrigo et al. 2002, Arrigo \& van Dijken 2003), and also decreased the incident light by preventing movement of sea ice, which thickened into multi-year ice, further lowering productivity (Thrush \& Cummings 2011). The epifaunal community difference we observed occurred 1 yr later than the infaunal shift (sensu Thrush \& Cummings 2011). It is possible that the larger epifaunal animals have sufficient food stores to delay the impacts of starvation, and also that enough of them are mobile, including the key species Odontaster validus and Sterechinus neumayeri, so that they can rapidly move into or out of an area as conditions change. Under low light conditions, the echinoderms may have migrated to shallower depths where there was better growth of benthic diatoms, and returned once the sea ice and light had normalized. The sessile species Zyzzyzus parvula, Laternula elliptica, and Alcyonium antarcticum also contributed to the shift in 2004. The temporary loss of the highly mobile and predatory species $(O$. validus and $S$. neumayeri) may have eliminated a 
recruitment filter that allowed the 3 sessile species to establish populations (sensu Dayton et al. 2016b).

In 2009, the epifaunal communities were different from other years at the chemically and organically contaminated sites, i.e. WQB Inner and Outfall, respectively, and Cape Armitage and WQB Outer. Additionally, at Turtle Rock and Explorers Cove, communities in 2009 may also have differed, although a low number of pairwise comparisons were significantly different (3/8 years and $2 / 6$ years, respectively; Table 6). The mega-icebergs cleared McMurdo Sound in 2005, but the sea ice in the Sound did not clear completely until 2008. We hypothesize that this latter epifaunal difference was also due to the movement of the mega-icebergs and clearing of the sea ice. Rather than the negative mechanism of motile species leaving due to lack of food, it may have been a positive mechanism with the same motile species moving to areas of high food concentrations (Kim et al. 2007). While Thrush et al. (2006) concluded that iceberg disturbance, light availability, and advection of planktonic food (proximity to open water), control benthic communities in McMurdo Sound, we note that ice disturbance and food availability may be intertwined. At Cinder Cones, we observed large 'falls' of Beggiatoa extending from a substantial ice disturbance in shallow water that had moved sediment and killed infauna in 2009, creating a food source for scavengers like $O$. validus and $S$. neumayeri (Thurber et al. 2017, S. Kim unpubl. data). Other benthic studies in McMurdo Sound (Norkko et al. 2007) also found that the type of food available and utilized (detrital or fresh) was dependent on ice cover.

The only other year of community differences (2002 at Outfall South A and Explorers Cove) was after mega-iceberg emplacement, and may indicate a more rapid community response at these particular sites. Dayton et al. (2016b) reported a massive sponge recruitment event on artificial substrates that encompassed both the east and west sides of McMurdo Sound in 2002-2004. Interestingly, equivalent recruitment did not occur on natural substrates, possibly prevented by a larval filter (Dayton et al. 2016b). Although we have no data prior to 2002, the changes we observed through 2004 support the occurrence of an ecological shift in the same time frame. The temporal shifts observed here may predict spatial differences at other (more southern) locales with more ice cover/less light availability (sensu Cummings et al. 2018). Extensive regional studies (Cummings et al. 2006, 2018, Lohrer et al. 2013) have shown that differences in sea ice cover, through light availability, impact the spatial distribution of benthic communities.

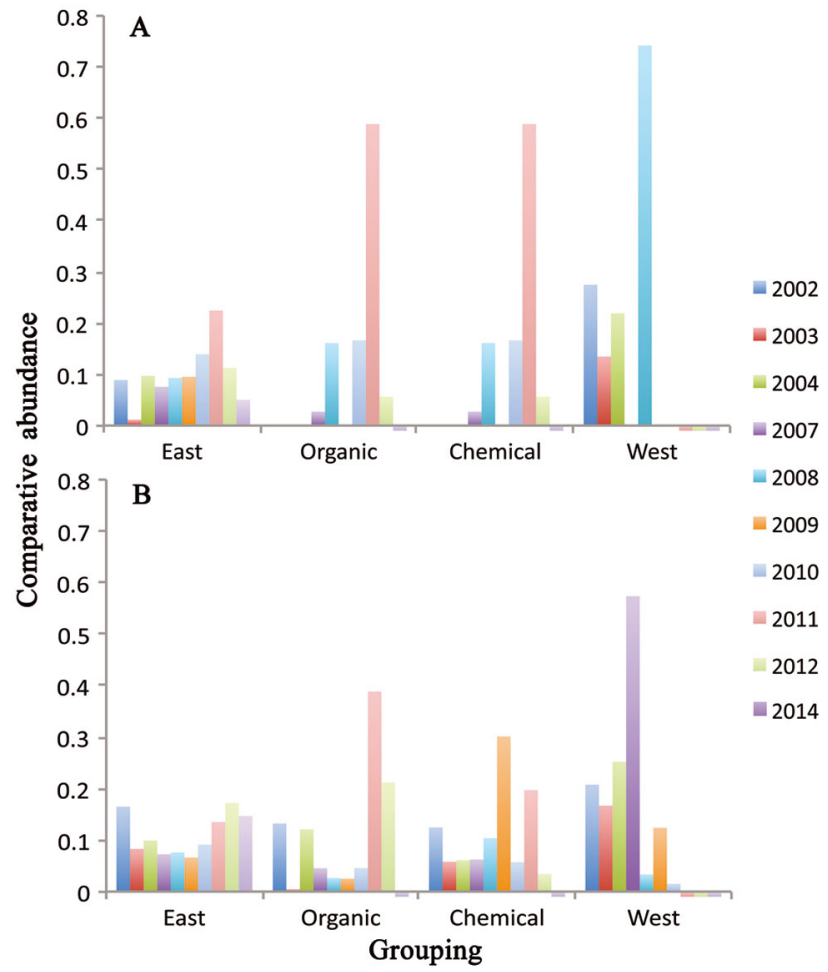

Fig. 3. Comparative abundance of epifauna in each spatially separated group, for each year sampled. Species were separated into feeders on (A) large particulates or (B) small particulates. Table S2 in the Supplement lists feeding type designations. Abundances of all species within a feeding type were summed, and because overall abundances varied significantly between sites, these values were standardized by the total for all years. To calculate the comparative abundance at all sites within a group, standardized abundances were summed relative to the number of sites. Sites that were sampled in 2 or fewer years were not included. Years that were not sampled are indicated by values of -0.01

The spatially widespread nature of the shifts, encompassing the East and West Sound, further supports a causal factor on the scale of the mega-icebergs influencing food availability. Dayton et al. (2019) hypothesized that there has been an additional shift in the size of food particulates, driven by increased glacial melt and nutrient input. The more frequently collected epifaunal data from our study suggest that the community shift was temporary. For the East side group, animals that feed on large particulates were less abundant in 2003-2010, and more abundant in 2002 and 2011-2014, while small particulate feeders were the opposite, with higher abundances in 2010-2012 and lower abundances in 2002-2009 and 2014 (Fig. 3, Table S2). Both the Organic and Chemical groups followed the same general pattern. In the West side group, the pattern was not clear. Animals that feed on small particulates 
Table 7. Comparison with species abundances $\left(\# \mathrm{~m}^{-2}\right.$, mean $\left.\pm \mathrm{SE}\right)$ from Dayton et al. (2019) in earlier years. For Odontaster validus: initial $=1967$, this study $=2002-2014 ;$ for Adamussium colbecki and Laternula elliptica: initial $=1977$, this study $=2002-2010$

\begin{tabular}{|lccc|}
\hline Species (site) & Initial & 2010 & This study \\
\hline $\begin{array}{c}\text { Odontaster validus } \\
\text { (Cape Armitage) }\end{array}$ & $13.00 \pm 2.89$ & $2.80 \pm 0.48$ & $3.11 \pm 3.38$ \\
$\begin{array}{c}\text { Adamussium colbecki } \\
\text { (Explorers Cove) }\end{array}$ & $7.70 \pm 3.04$ & $1.27 \pm 0.56$ & $5.93 \pm 9.56$ \\
$\begin{array}{c}\text { Laternula elliptica } \\
\text { (Explorers Cove) }\end{array}$ & $22.64 \pm 11.47$ & $0.00 \pm 0.00$ & $0.38 \pm 0.49$ \\
\hline
\end{tabular}

were very abundant in 2008, and less so both before and after. This supports the mega-icebergs, which were also temporary, as the main causal factor, although there appears to be a 3-6 yr lag in the system, at least for the epifauna.

\subsection{Species contributions}

The species characteristic of the East side grouping were $O$. validus and L. elliptica. Abundances of $O$. validus were overall much higher at Cinder Cones and Turtle Rock, as well as at Cape Evans and Horseshoe Bay; the latter 2 were sampled only once each. These 4 sites are all at the northern end of McMurdo Sound, although $O$. validus were not abundant at Cape Royds, the other northern site. O. validus were additionally found at 1 West side site, Cape Chocolate, but not at Explorers Cove or Cape Bernacchi. An extremely opportunistic motile species, O. validus is very patchily distributed depending on local food sources. L. elliptica was present only in very low numbers at both Organic and Chemical sites, as well as at all West side sites. One commonality between these sites is the presence of stressors, either contaminants or lack of food ${ }_{i}$ L. elliptica may be more sensitive than other species. We can also make comparisons with earlier data collected at Cape Armitage in 1967, and Explorers Cove 1974-1979 (Table 7). Dayton et al. (2019) noted a decrease in 3 important species, O. validus at Cape Armitage and L. elliptica and Adamussium colbecki at Explorers Cove, between initial sampling years and 2010. Our data confirm that the decrease is persistent in $O$. validus and $L$. elliptica, and occurred before 2002.

The Temporal group key species were $Z$. parvula and $A$. antarcticum. Z. parvula was abundant at sites that had occasional chunks of hard substrate, but not if there was chemical contamination. Abun- dances were low in 2002, 2003, and 2007. A. antarcticum distribution was similar; it was found on hard substrates, not at chemically contaminated sites, and increased in latter years. Both of these species feed on large particulates, and their increase is further suggestive of community recovery from the lean mega-iceberg years. We note that a complicating factor is the past and ongoing release of gravel- to bouldersized sediments from activities at McMurdo Station. In the early 1960 s, all of the station front sites were entirely fine sediments, but now they include varying levels of added coarse debris (S. Kim et al. unpubl. data). These provide substrate for settlement of sessile organisms and may lead to increases in abundances over time; however, the majority of the additional sediment was added prior to 2002 at Outfall South B, Transition, Outfall South A, Jetty North, Road, and Jetty (in decreasing order of disturbance). WQB Middle and Inner are more strongly and recently impacted because of their proximity to the ice pier, where terrestrial sediments are used annually for construction and maintenance. WQB Inner is additionally impacted by clearing of drainage ditches around McMurdo, which leads to heavy runoff of melt-water transporting fine sediments to the site. However, the extreme chemical contamination of these sites may prevent settlement and survival of many organisms.

$S$. neumayeri, which was characteristic of the Organic group (Outfall site), also had high abundances at Turtle Rock, but was low at WQB Inner, WQB Middle, and WQB Outer, as well as the West side sites Cape Bernacchi and Explorers Cove, and in 2003. Like other echinoderms, S. neumayeri is sensitive to chemical stressors but not to organic contamination (Lenihan et al. 2003), and is widely opportunistic and motile and consequently patchily distributed. A. colbecki, characteristic of the West side community, generally increased during the 20032004 time frame. These scallops are quite motile and, like $O$. validus and $S$. neumayeri, may track local food resources such as the outflow of phytoplanktonrich water from the nearshore freshwater moat at Explorers Cove (Dayton et al. 2019). Dayton et al. (2019) noted a decrease in $A$. colbecki between the 1970s and 2010; however, the abundance of A. colbecki was highly variable between 2002 and 2010 (Table 7), suggesting that the previously noted decrease is not a long-term pattern. An apparent recruitment event of this species also occurred on the east side in 2008, or earlier enough that the bivalves were visible in images in 2008. 


\subsection{Environmental and spatial details}

If difference in available food was the mechanism of change, we might expect to observe correlations with sediment TOC, which we did not. However, our samples were collected early in the spring, before the annual bloom, and may not fully reflect seasonal food availability.

Sites that were sampled only once confirmed the overall spatial pattern of community differences. East side sites were generally similar to sites in the same spatial area. However, Cape Chocolate on the west side of the sound was not like other West side sites and instead was similar to the chemically contaminated site WQB Inner. Cape Chocolate extends past a small island at the southern end of Salmon Bay, a location that underwent a massive flood and sediment deposition event sometime between 1990 and 2010 (Dayton et al. 2016a). It is possible that the resemblance between the sites is because both were severely disturbed, although the mechanisms of disturbance were different.

\subsection{Summary}

In eastern McMurdo Sound, a community change took place in 2004, and a less widespread one in 2009. We suggest this was due to the temporary presence of mega-icebergs at the mouth of McMurdo Sound, in support of conclusions made previously by Conlan et al. (2010, for infauna) and Dayton et al. (2019). The mega-icebergs entered the Sound in 2000 and left in 2005; thus, on the east side of the Sound, there appears to be a lag of $4 \mathrm{yr}$ between a shift in food resources and detectable change in the epifaunal community. The shift was earlier on the westside, already underway between 2002 and 2003, suggesting the community in this food-poor region is more immediately responsive to changes in food availability. West side sampling ceased in 2010 and we did not see a change between 2009 and 2010; it is possible that the West side community is not only quicker to starve to but also slower to recover.

The community shifts may be due to a difference in quality of food (size of particulates) as well as quantity. Several key species in this system are mobile and quickly respond to shifting food sources. This leads to patchy distributions and high variability. Key species also generally feed on large particulates (among other things) and were less abundant at $18 \mathrm{~m}$ depth during the iceberg years. A concomitant increase in sessile, small-particulate feeders demonstrates that the community change was not entirely due to transient mobility. We have shown that Antarctic epifaunal communities, so long considered stable on century scales, are dynamic on the time scale of years.

Acknowledgements. Numerous people contributed to this paper over the many years of data collection and analysis, and we are grateful to all of them. Key people we want to thank include John Oliver, Jim Oakden, Dan Malone, Jen Fisher, Rusty Fairey, Clint Collins, and D. J. Osborne. We are also indebted to the many McMurdo Station support personnel, especially Rob Robbins and Steve Rupp. Financial support was provided by ABA, CC\&R, the David and Judy Zaches Foundation, and NSF grant numbers OPP0126319, OPP-0619622, OPP-0944557, ANT-0842064, and ANT-0944747. Any opinions, findings, and conclusions or recommendations expressed in this material are those of the authors and do not necessarily reflect the views of the NSF.

\section{LITERATURE CITED}

Anderson MJ, Gorley RN, Clarke RK (2008) PERMANOVA+ for PRIMER: guide to software and statistical methods. Primer-E, Plymouth

Arrigo KR, van Dijken GL (2003) Impact of iceberg C 19 on Ross Sea primary production. Geophys Res Lett 30:1836

Arrigo KR, van Dijken GL (2004) Annual changes in sea-ice, chlorophyll $a$, and primary production in the Ross Sea, Antarctica. Deep Sea Res II 51:117-138

Arrigo KR, van Dijken GL, Ainley DG, Fahnestock MA, Markus T (2002) Ecological impact of a large Antarctic iceberg. Geophys Res Lett 29:1104

* Baettig MB, Wild M, Imboden DM (2007) A climate change index: where climate change may be most prominent in the 21st century. Geophys Res Lett 34:L01705

*Barnes DK (1999) The influence of ice on polar nearshore benthos. J Mar Biol Assoc UK 79:401-407

* Barry JP, Dayton PK (1988) Current patterns in McMurdo Sound, Antarctica and their relationship to local biotic communities. Polar Biol 8:367-376

Beckman Coulter (2003) LS 13320 particle size analyzer manual PN 7222061A. Beckman Coulter, Inc., Miami, FL

Bramer M (2013) Principles of data mining. Springer Publishing Company, London

Brown KM, Fraser KP, Barnes DK, Peck LS (2004) Links between the structure of an Antarctic shallow-water community and ice-scour frequency. Oecologia 141:121-129

* Cavalieri DJ, Parkinson CL (2008) Antarctic sea ice variability and trends, 1979-2006. J Geophys Res Oceans 113: $\mathrm{C} 07004$

Chavez FP, Ryan J, Lluch-Cota SE, Niquen M (2003) From anchovies to sardines and back: multidecadal change in the Pacific Ocean. Science 299:217-221

Conlan KE, Kim SL, Lenihan HS, Oliver JS (2004) Benthic changes during 10 years of organic enrichment by McMurdo Station, Antarctica. Mar Pollut Bull 49:43-60

* Conlan KE, Kim SL, Thurber AR, Hendrycks E (2010) Benthic changes at McMurdo Station, Antarctica following local sewage treatment and regional iceberg-mediated productivity decline. Mar Pollut Bull 60:419-432

* Cummings V, Thrush S, Norkko A, Andrew N, Hewitt J, Funnell G, Schwarz AM (2006) Accounting for local scale 
variability in benthos: implications for future assessments of latitudinal trends in the coastal Ross Sea. Antarct Sci 18:633-644

* Cummings VJ, Hewitt JE, Thrush SF, Marriott PM, Halliday NJ, Norkko AM (2018) Linking Ross Sea coastal benthic communities to environmental conditions: documenting baselines in a spatially variable and changing world. Front Mar Sci 5:232

* Dayton PK, Oliver JS (1977) Antarctic soft-bottom benthos in oligotrophic and eutrophic environments. Science 197: 55-58

Dayton PK, Robilliard GA (1971) The benthic community near McMurdo station. Antarct J US 6:54-56

* Dayton PK, Tegner MJ (1984) Catastrophic storms, El Niño, and patch stability in a southern California kelp community. Science, 224:283-285

* Dayton PK, Robilliard GA, Paine RT, Dayton LB (1974) Biological accommodation in the benthic community at McMurdo Sound, Antarctica. Ecol Monogr 44:105-128

* Dayton PK, Watson D, Palmisano A, Barry JP, Oliver JS, Rivera D (1986) Distribution patterns of benthic microalgal standing stock at McMurdo Sound, Antarctica. Polar Biol 6:207-213

* Dayton PK, Mordida BJ, Bacon F (1994) Polar marine communities. Am Zool 34:90-99

* Dayton PK, Tegner MJ, Edwards PB, Riser KL (1999) Temporal and spatial scales of kelp demography: the role of oceanographic climate. Ecol Monogr 69:219-250

Wayton PK, Hammerstrom K, Jarrell SC, Kim S, Nordhausen W, Osborne DJ, Thrush SF (2016a) Unusual coastal flood impacts in Salmon Valley, McMurdo Sound, Antarctica. Antarct Sci 28:269-275

* Dayton P, Jarrell S, Kim S, Thrush S, Hammerstrom K, Slattery M, Parnell E (2016b) Surprising episodic recruitment and growth of Antarctic sponges: implications for ecological resilience. J Exp Mar Biol Ecol 482:38-55

* Dayton PK, Jarrell S, Kim S, Parnell P, Thrush S, Hammerstrom K, Leichter J (2019) Benthic responses to an Antarctic regime shift: food particle size and recruitment biology. Ecol Appl 29:e01823

№ney SC, Ruckelshaus M, Duffy JE, Barry JP and others (2012) Climate change impacts on marine ecosystems. Annu Rev Mar Sci 4:11-37

Eicken H (1992) The role of sea ice in structuring Antarctic ecosystems. In: Hempel G (ed) Weddell Sea ecology. Springer, Berlin, p 1-13

Francis RC, Hare SR, Hollowed AB, Wooster WS (1998) Effects of interdecadal climate variability on the oceanic ecosystems of the NE Pacific. Fish Oceanogr 7:1-21

* Gómez I, Wulff A, Roleda MY, Huovinen P and others (2009) Light and temperature demands of marine benthic microalgae and seaweeds in polar regions. Bot Mar 52: 593-608

Gutt J (2001) On the direct impact of ice on marine benthic communities, a review. Polar Biol 24:553-564

*Hoegh-Guldberg O, Bruno JF (2010) The impact of climate change on the world's marine ecosystems. Science 328 : 1523-1528

Holland PR, Kwok R (2012) Wind-driven trends in Antarctic sea-ice drift. Nat Geosci 5:872-875

*HHunt BP, Hosie GW (2003) The Continuous Plankton Recorder in the Southern Ocean: a comparative analysis of zooplankton communities sampled by the CPR and vertical net hauls along $140^{\circ}$ E. J Plankton Res 25:1561-1579

IPCC (Intergovernmental Panel on Climate Change) (2014)
Climate change 2014 - impacts, adaptation and vulnerability: regional aspects. Cambridge University Press, Cambridge

Kim SL, Thurber A, Hammerstrom K, Conlan K (2007) Seastar response to organic enrichment in an oligotrophic polar habitat. J Exp Mar Biol Ecol 346:66-75

*Kim S, Saenz B, Scanniello J, Daly K, Ainley D (2018) Local climatology of fast ice in McMurdo Sound, Antarctica. Antarct Sci 30:125-142

* Lee S, Feldstein SB (2013) Detecting ozone- and greenhouse gas-driven wind trends with observational data. Science 339:563-567

Lenihan HS (1992) Benthic marine pollution around McMurdo Station, Antarctica: a summary of findings. Mar Pollut Bull 25:318-323

Kenihan HS, Oliver JS (1995) Anthropogenic and natural disturbances to marine benthic communities in Antarctica. Ecol Appl 5:311-326

Kenihan HS, Oliver JS, Oakden JM, Stephenson MD (1990) Intense and localized benthic marine pollution around McMurdo Station, Antarctica. Mar Pollut Bull 21:422-430

* Lenihan HS, Kiest KA, Conlan KE, Slattery PN, Konar BH, Oliver JS (1995) Patterns of survival and behavior in Antarctic benthic invertebrates exposed to contaminated sediments: field and laboratory bioassay experiments. J Exp Mar Bio Ecol 192:233-255

Lenihan HS, Peterson CH, Kim SL, Conlan KE and others (2003) Variation in marine benthic community composition allows discrimination of multiple stressors. Mar Ecol Prog Ser 261:63-73

Kohrer AM, Cummings VJ, Thrush SF (2013) Altered sea ice thickness and permanence affects benthic ecosystem functioning in coastal Antarctica. Ecosystems 16:224-236

*Maksym T, Stammerjohn SE, Ackley S, Massom R (2012) Antarctic sea ice-a polar opposite? Oceanography 25: 140-151

*Massom RA, Stammerjohn SE (2010) Antarctic sea ice change and variability-physical and ecological implications. Polar Sci 4:149-186

* Mincks SL, Smith CR, DeMaster DJ (2005) Persistence of labile organic matter and microbial biomass in Antarctic shelf sediments: evidence of a sediment 'food bank'. Mar Ecol Prog Ser 300:3-19

Norkko A, Thrush SF, Cummings VJ, Gibbs MM, Andrew NL, Norkko J, Schwarz AM (2007) Trophic structure of coastal Antarctic food webs associated with changes in sea ice and food supply. Ecology 88:2810-2820

* Pauly D, Christensen V, Dalsgaard J, Froese R, Torres F (1998) Fishing down marine food webs. Science 279:860-863

* Priscu JC (2016) Unraveling ecosystem responses to climate change on the Antarctic continent through long-term ecological research. Bioscience 66:799-800

* Remy JP, Becquevort S, Haskell TG, Tison JL (2008) Impact of the B-15 iceberg "stranding event" on the physical and biological properties of sea ice in McMurdo Sound, Ross Sea, Antarctica. Antarct Sci 20:593-604

Scheffer M, Carpenter S, Foley JA, Folke C, Walker B (2001) Catastrophic shifts in ecosystems. Nature 413:591-596

* Schofield O, Ducklow HW, Martinson DG, Meredith MP, Moline MA, Fraser WR (2010) How do polar marine ecosystems respond to rapid climate change? Science 328: 1520-1523

Seibel BA, Dierssen HM (2003) Cascading trophic impacts of reduced biomass in the Ross Sea, Antarctica: Just the tip of the iceberg? Biol Bull (Woods Hole) 205:93-97 
Slattery M, McClintock JB, Bowser SS (1997) Deposit feeding: a novel mode of nutrition in the Antarctic colonial soft coral Gersemia antarctica. Mar Ecol Prog Ser 149: 299-304

Smale DA (2007) Ice disturbance intensity structures benthic communities in nearshore Antarctic waters. Mar Ecol Prog Ser 349:89-102

Smith CR, Mincks S, DeMaster DJ (2006a) A synthesis of bentho-pelagic coupling on the Antarctic shelf: food banks, ecosystem inertia and global climate change. Deep Sea Res II 53:875-894

Smith WO Jr, Shields AR, Peloquin JA, Catalano G, Tozzi S, Dinniman MS, Asper VA (2006b) Interannual variations in nutrients, net community production, and biogeochemical cycles in the Ross Sea. Deep Sea Res II 53: 815-833

Stockton WL (1984) The biology and ecology of the epifaunal scallop Adamussium colbecki on the west side of McMurdo Sound, Antarctica. Mar Biol 78:171-178

Tegner MJ, Dayton PK, Edwards PB, Riser KL (1996) Is there evidence for long-term climatic change in southern California kelp forests? Calif Coop Ocean Fish Invest Rep 37: 111-126

Editorial responsibility: James McClintock, Birmingham, Alabama, USA
Thrush SF, Cummings VJ (2011) Massive icebergs, alteration in primary food resources and change in benthic communities at Cape Evans, Antarctica. Mar Ecol 32: 289-299

Thrush S, Dayton P, Cattaneo-Vietti R, Chiantore M and others (2006) Broad-scale factors influencing the biodiversity of coastal benthic communities of the Ross Sea. Deep Sea Res II 53:959-971

* Thrush SF, Hewitt JE, Dayton PK, Coco G and others (2009) Forecasting the limits of resilience: integrating empirical research with theory. Proc R Soc B 276:3209-3217

Thurber AR, Seabrook S, Welsh R (2017) Methane cycling in the High Antarctic-paradigms lost? XIIth SCAR Biology Symposium Book of Abstracts, p 243. https://web. whoi.edu/cbe6/wp-content/uploads/sites/84/2017/08/20 Thurber.pdf

* Tunberg BG, Nelson WG (1998) Do climatic oscillations influence cyclical patterns of soft bottom macrobenthic communities on the Swedish west coast? Mar Ecol Prog Ser 170:85-94

* Turner J, Barrand NE, Bracegirdle TJ, Convey P and others (2014) Antarctic climate change and the environment: an update. Polar Rec 50:237-259

Submitted: October 4, 2018; Accepted: February 13, 2019

Proofs received from author(s): March 9, 2019 